\title{
VITAMIN D AND PROSTATE CANCER
}

I. Kostoglou-Athanassiou ${ }^{1,2}$, E. Papageorgiou ${ }^{1}$, A. Armakolas ${ }^{1}$, M. Koutsilieris ${ }^{1}$

${ }^{1}$ Department of Experimental Physiology, Medical School, University of Athens, Greece

${ }^{2}$ Department of Endocrinology, Red Cross Hospital, Athens, Greece

\section{OBJECTIVES}

The anticancer action of vitamin D is currently considered one of its main properties. The main actions of vitamin $D$ are related to the regulation of calcium levels and the normal function of the musculoskeletal system. However, its anticancer action is currently in the focus of research interests.

The aim was to study the effect of vitamin D on PC3 human prostate cancer cells in vitro.

\section{METHODS}

The effect of $1,25(\mathrm{OH})_{2} \mathrm{D}_{3}$ (Sigma-Aldrich) at concentrations of $1 \mu \mathrm{M}$ and $200 \mathrm{nM}$ on PC3 human breast cancer cells was studied in vitro. PC3 human prostate cancer cells were incubated for $48 \mathrm{~h}$ at a temperature of $37^{\circ} \mathrm{C}$ with progressively decreasing concentrations of $1,25(\mathrm{OH})_{2} \mathrm{D}_{3}$. PC3 cells were also incubated with progressively decreasing concentrations of $1,25(\mathrm{OH})_{2} \mathrm{D}_{3}$ (the initial concentration of $1,25(\mathrm{OH})_{2} \mathrm{D}_{3}$ being $200 \mathrm{nM}$ ) in the presence of the antimitotic agent docetaxel $50 \mathrm{nM}$.

\section{RESULTS}

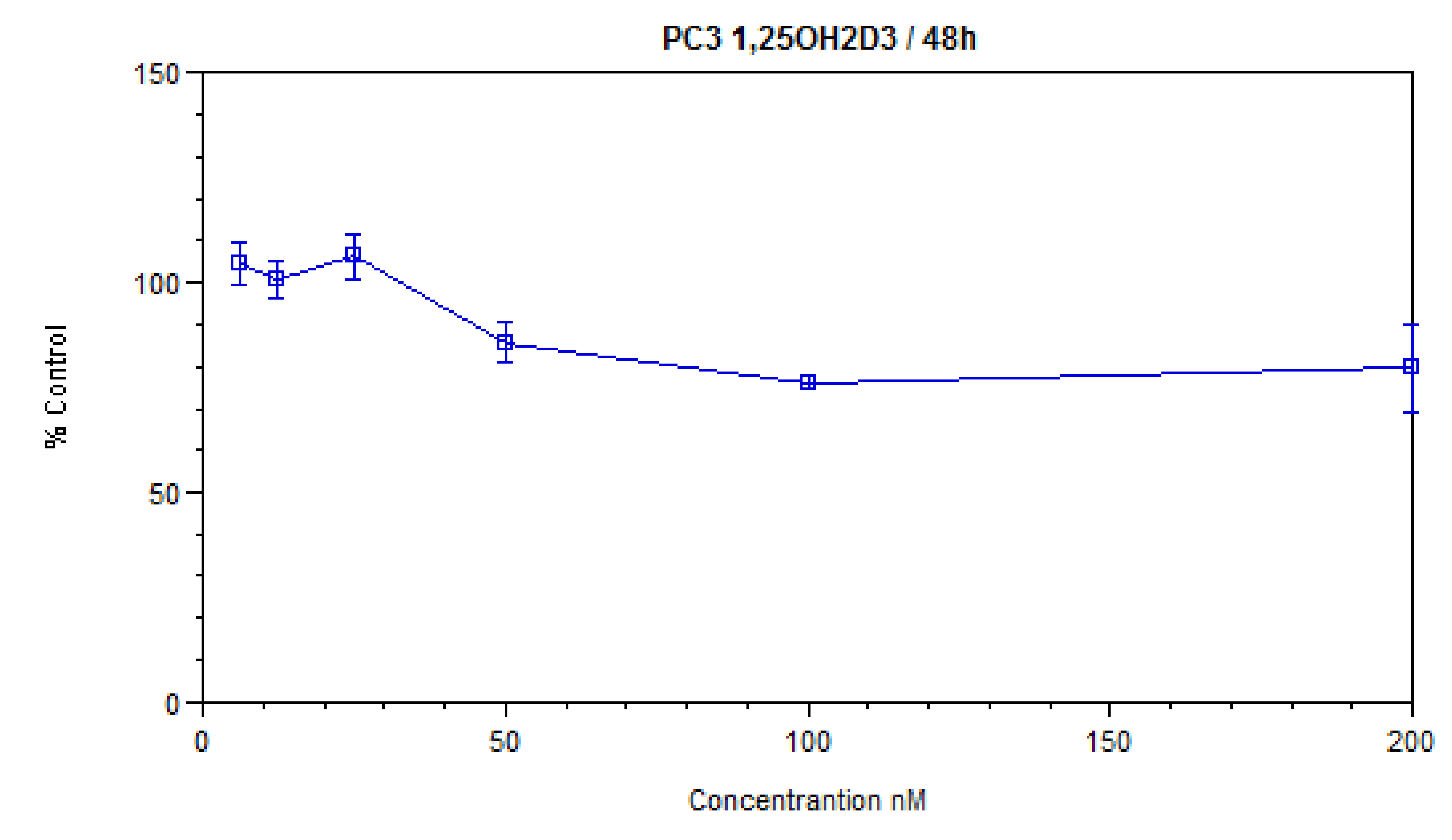

A mild inhibition of the proliferation of human prostate cancer cells was observed after $48 \mathrm{~h}$ incubation with $1,25(\mathrm{OH})_{2} \mathrm{D}_{3}$ only at high concentrations. After simultaneous incubation with $1,25(\mathrm{OH})_{2} \mathrm{D}_{3}$ and docetaxel intense inhibition of the proliferation of PC3 prostate cancer cells was observed.

\section{CONCLUSIONS}

In conclusion, a mild inhibitory effect of $1,25(\mathrm{OH})_{2} \mathrm{D}_{3}$ on the proliferation of PC3 human prostate cancer cells was observed, while the antimitotic agent docetaxel had intense inhibitory effect on their proliferation. 